Jurnal PAIRaden Fatah

Vol. 2, No. 1, (Januari 2020): 45-59

\title{
HUBUNGAN KEMANDIRIAN BELAJAR DENGAN HASIL BELAJAR SISWA KELAS VII PADA MATA PELAJARAN PENDIDIKAN AGAMA ISLAM DI SMP NEGERI 1 BANYUASIN III
}

Linda Sari

Universitas Islam Negeri Raden

Fatah Palembang

lindasari7563@gmail.com

Abdurrahmansyah

Universitas Islam Negeri Raden

Fatah Palembang

abdurrahmansyah@radenfatah.ac.id

Aida Imtihana

Universitas Islam Negeri Raden

Fatah Palembang

aidaimtihana@radenfatah.ac.id
Abstract

In the learning process that occurs in SMP Negeri 1 Banyuasin III, making students not accustomed to completing the tasks obtained by their own efforts because the occurrence of this process of learning independence is the lack of willingness in students to learn more actively and focus on the learning process. The purpose of this study was to determine the relationship between learning independence and learning outcomes of Grade VII students in Islamic Religion Education subjects at SMP Negeri 1 Banyuasin III.

This type of research is quantitative research. The object of the informants in this study are the principal, Islamic Religious Education teachers and students of SMP Negeri 1 Banyuasin III. The type of data used is the type of quantitative data. There are two sources of data used, namely primary data obtained from principals, teachers and students, and secondary data derived from documents and literature that support this research. The data collection techniques in the form of observation, questionnaires and documentation. Then do the analysis using statistical analysis, namely the product moment correlation formula (Pearson)

The results of this study with the known product moment correlation value is 0.552 and consulted with the $" r$ " product moment tab turns out that the price is greater than the level of $5 \%$ or $1 \%(0.374<0.552>0.478)$. With this the $\mathrm{Ha}$ (alternative hypothesis) is accepted and Ho (the null hypothesis) is rejected so that it is concluded that there is a relationship of learning independence with the learning outcomes of Grade VII students in Islamic Religious Education subjects at SMP Negeri 1 Banyuasin III, therefore $\mathrm{Ha}$ is accepted and $\mathrm{Ho}$ is rejected so prevailing hypothesis that reads there is a relationship of learning independence with student learning outcomes in class VII on Islamic Religious Education subjects at SMP Negeri 1 Banyuasin III.

Keywords: Learning Independence, Learning Outcomes 


\section{PENDAHULUAN}

Kegiatan utama dalam pendidikan di sekolah adalah kegiatan belajar mengajar. Belajar merupakan proses dimana suatu organisme mengubah perilakunya karena hasil dari pengalamannya. Sedangkan mengajar adalah suatu aktivitas mengorganisasi atau mengatur lingkungan sebaik-baiknya dan menghubungkan dengan anak sehingga terjadi proses belajar. ${ }^{1}$ Proses kegiatan belajar mengajar merupakan penentu keberhasilan dalam mencapai tujuan pendidikan karena siswa yang belajar diharapkan mengalami perubahan baik dalam bidang pengetahuan, pemahaman, keterampilan, nilai maupun sikapnya.

Belajar sendiri merupakan aktivitas yang dilakukan siswa dengan memperoleh perubahan tingkah laku sebagai hasilnya. Sedangkan kemandirian diartikan sebagai suatu kekuatan internal individu dan diperoleh melaui proses individual yang berupa proses realisasi kemandirian dan proses menuju kesempurnaan. $^{2}$ Dapat dipahami bahwasanya kemandirian belajar merupakan aktivitas belajar yang berlangsung lebih didorong oleh kemauan sendiri, pilihan sendiri dan tanggung jawab dari siswa.

Kemandirian belajar adalah suatu proses yang dinamik dimana siswa membangun pengetahuan, keterampilan, dan sikap pada saat mempelajari konteks yang spesifik. Untuk itu siswa perlu memiliki berbagai strategi belajar, pengalaman menerapkannya dalam berbagai situasi, dan mampu merefleksi secara efektif. $^{3}$

Di lembaga pendidikan yang bersifat formal seperti sekolah, keberhasilan pendidikan dapat dilihat dari hasil belajar siswa dalam prestasi belajarnya. Kualitas dan keberhasilan belajar siswa sangat dipengaruhi oleh kemampuan dan ketetapan guru memilih dan menggunakan model dan media pembelajaran. Kenyataan dilapangan, khususnya dalam mata pelajaran Pendidikan Agama Islam, kegiatan

${ }^{1}$ Muhibbin Syah, Psikologi Belajar (Depok: Rajawali Pers, 2017), hlm. 179.

${ }^{2}$ M. Ali dan Anshori, Psikologi Pendidikan (Jakarta: Rineka Cipta, 2010), hlm. 71.

${ }^{3}$ Ratnaningsih, "Pengaruh Pembelajaran Kontekstual terhadap Kemampuan Berpikir Kritis dan Kreatif Matematik serta Belajar mandiri Siswa Sekolah Menengah Atas" (Disertasi UPI Bandung, 2007), hlm. 38. 
Vol. 2, No. 1, (Januari 2020): 45-59

pembelajarannya masih dilakukan secara klasikal. Pembelajaran lebih ditekankan pada metode yang banyak diwarnai dengan ceramah dan bersifat guru sentries. ${ }^{4}$

Menurut Hamalik, hasil belajar adalah sebagai terjadinya perubahan tingkah laku pada diri seseorang yang dapat diamati dan diukur bentuk pengetahuan, sikap dan keterampilan. Perubahan tersebut dapat diartikan sebagai terjadinya peningkatan dan pengembangan yang lebih baik dari sebelumnya dan yang tidak tahu menjadi tahu. Sedangkan menurut Dimyanti dan Mudjiono bahwa hasil belajar merupakan hal yang dapat dipandang dari dua sisi, yaitu sisi siswa dan sisi guru, dari sisi siswa hasil belajar merupakan tingkat perkembangan mental yang lebih baik bila dibandingkan pada saat sebelum belajar. Tingkat perkembangan mental tersebut terwujud pada jenis-jenis ranah kognitif, afektif dan psikomotorik. Sedangkan dari sisi guru hasi belajar merupakan terselesaikannya bahan pelajaran. ${ }^{5}$

Berdasarkan hasil observasi yang peneliti lakukan ditemukan beberapa fakta mengenai kemandirian belajar dan hasil belajar siswa kelas VII di SMP Negeri 1 Banyuasin III adalah dilihat dari kemandirian belajar sebagian siswa tidak mampu menyelesaikan tugas sendiri setelah guru memberikan materi pelajaran. Kondisi yang terjadi di SMP Negeri 1 Banyuasin III ini, membuat siswa tidak terbiasa menyelesaikan tugas yang didapat dengan usaha sendiri sebab terjadinya proses kemandirian belajar ini ialah kurangnya kemauan dalam diri siswa untuk belajar lebih fokus dalam berlangsungnya proses belajar. Sedangkan mengenai hasil belajar yang diperoleh dari guru mata pelajaran Pendidikan Agama Islam bahwasanya banyak siswa masih mendapat nilai KKM dibawah rata-rata. ${ }^{6}$

${ }^{4} \mathrm{~K}$. Karliana, "Pengaruh penerapan investigasi kelompok dibantu dengan multimediainteraktif terhadap peningkatan hasil belajar siswa pada mata pelajaran PAI di SMA Yanitas Palembang," Tadrib: Jurnal Pendidikan Agama Islam 2, no. 1 (2017), hlm. 2.

${ }^{5}$ Nurastanti, Fajri Ismail, dan Sukirman, "Pengaruh lingkungan belajar di sekolah terhadap hasil belajar siswa pada mata pelajaran fiqih kelas XI Madrasah Aliyah Negeri 1 Banyuasin," Jurnal PAI Raden Fatah 1, no. 1 (2017), hlm. 42.

${ }^{6}$ Hasil Observasi Lapangan di SMPN 1 Banyuasin III pada tanggal 23 Januari 2019. 


\section{METODE PENELITIAN}

Metode penelitian adalah cara-cara yang dapat digunakan oleh peneliti untuk mengumpulkan data. ${ }^{7}$ Penelitian akan menjelaskan metode yang akan peneliti pergunakan, maka dijelaskan mengenai jenis penelitian, populasi dan sampel penelitian, jenis dan sumber data, teknik pengumpulan data dan teknik analisis data.

Jenis data kualitatif adalah data-data yang dinyatakan dalam angka-angka. dimaksudkan untuk mengetahui tentang jumlah siswa, sarana dan prasarana dan lain-lain. Data kuantitatif adalah data yang berkenaan dengan serangkaian observasi, dokumentasi, dari pihak sekolah, data hasil wawancara kepala sekolah dan guru Pendidikan Agama Islam.

Populasi menurut Sugiono, populasi adalah wilayah generalisasi yang terdiri atas subyek dan obyek yang mempunyai kualitas dan karakteristik tertentu yang ditetapkan oleh peneliti untuk dipelajari kemudian ditarik kesimpulannya. Adapun populasi dalam penelitian ini adalah seluruh siswa kelas VII SMP Negeri 1 Banyuasin III dengan jumlah 232 siswa.

Dari hasil diatas dapat disimpulkan bahwa teknik penarikan sampelnya jika dibulatkan menjadi 30 sampel yaitu menggunakan teknik Cluster Sampling yaitu teknik pengambilan sampel berdasarkan kelompok tertentu.

Teknik pengumpulan data pada penelitian angket atau kuesioner merupakan cara pengumpulan data berbentuk pengajuan pernyataan tertulis melalui sebuah daftar pertanyaan yang sudah dipersiapkan. ${ }^{8}$

Observasi adalah suatu metode dengan cara mengamati atau mengunjungi lokasi sebagai tempat objek penelitian untuk mengambil data tentang keadaan lokasi penelitian.

Dokementasi merupakan suatu teknik pengumpulan data yang menghimpun dan menganalisis dokumen-dokumen, baik dokumen tertulis gambar maupun elektronik. Dokumentasi yang menunjang guna menjawab pertanyaan

${ }^{7}$ Suharsimi Arikunto, Prosedur Penelitian Suatu Pendekatan Praktek (Jakarta: Rineka Cipta, 2013), hlm. 100.

${ }^{8}$ Anas Sudijono, Pengantar Evaluasi Pendidikan (Jakarta: Grafindo Prasada, 2015), hlm. 30. 
Vol. 2, No. 1, (Januari 2020): 45-59

dalam penelitian khususnya data hasil belajar siswa kelas VII.A di SMP Negeri 1 Banyuasin III.

Angket adalah teknik pengumpulan data yang dilakukan dengan cara memberi seperangkat pertanyaan atau pernyataan tertulis kepada responden untuk di jawabnya. Untuk menentukan valid tidaknya angket digunakan, maka peneliti menggunakan rumus uji validitas, sebagai berikut:

a. Uji Validitas Instrumen

$$
r=\frac{\mathrm{N}\left(\sum X Y\right)-\left(\sum X \cdot \sum y\right)}{\sqrt{\left[\left(N \sum X_{n}^{2}-\left(\sum X\right) \frac{2}{n}\right)\right]\left[\left(N \sum Y_{n}^{2}-\left(\sum Y\right) \frac{2}{n}\right)\right]}}
$$

Keterangan:

$\mathrm{V}$ : Validitas.

$\Sigma \mathrm{X}:$ Jumlah sub variabel bebas+sub variabel terikat.

$\Sigma Y$ : Jumlah soal yang berhubungan langsung dengan sub variabel.

$\Sigma \mathrm{Sv}$ : Jumlah soal seluruhnya.

Dan peneliti juga menggunakan rumus uji reabilitas :

b. Uji Reliabilitas Instrumen

$$
r_{1}=\frac{2 r_{\mathrm{xy}}}{1+r_{\mathrm{xy}}}
$$

\section{Keterangan:}

$\mathrm{r}_{1}=$ reabilitas internal

$\mathrm{r}_{\mathrm{xy}}=$ korelasi product moment antara belahan ganjil dan genap

Dalam penelitian ini penulis menggunakan desain pengukuran yang berupa skala likert. Jawaban setiap item instrument yang digunakan skala likert dengan 5 kategori. Pertanyaan bersifat positif diberi skor 5,4,3,2 dan untuk yang bersifat negatif 2,3,4,5 yang dapat berupa positif.

Teknik analisis data, Uji hipotesis digunakan untuk menguji kebenaran hipotesis yang diajukan. Adapun jalannya adalah melalui pengolahan data yang akan mencari korelasi antara variabel independen $(\mathrm{X})$ dengan variabel dependen (Y) dengan dicari menggunakan korelasi Product moment. Mencari korelasi antara kriterium (Y) dengan prediktor (X) melalui teknik korelasi product moment dari Pearson, sebagai berikut: 
$r_{\mathrm{xy}}=\frac{\mathrm{N}\left(\sum X Y\right)-\left(\sum X . \sum Y\right)}{\sqrt{\left[\left(N \sum X_{n}^{2}-\left(\sum X\right) \frac{2}{n}\right)\right]\left[\left(N \sum Y_{n}^{2}-\left(\sum Y\right)_{\bar{n}}^{2}\right)\right]}}$

Keterangan :

rxy = Angka Indeks Kolerasi "r" Product Moment

$\mathrm{N}=$ Number of Case (jumlah responden)

$\Sigma \mathrm{X}=$ Jumlah Seluruh $\mathrm{X}$

$\Sigma \mathrm{Y}=$ Jumlah Seluruh $\mathrm{Y}$

Setelah rxy diketahui, kemudian menarik kesimpulan yang dilakukan dengan cara dikonsultasikan dengan tabel nilai $\mathrm{r}$ product moment pada taraf signifikansi $5 \%$ dan $1 \%$. Jika $\mathrm{r}$ hitung, $\geq \mathrm{r}$ tabel maka Ha (Hipotesis Alternatif) diterima dan sebaliknya, Ho (Hipotesis Nihil) ditolak. Berarti memang benar antara Variabel X dan Variabel Y terdapat korelasi positif yang signifikan.

\section{HASIL DAN PEMBAHASAN}

\section{A. Kemandirian Belajar Siswa Kelas VII.A Pada Mata Pelajaran Pendidikan Agama Islam di SMP Negeri 1 Banyuasin III}

Untuk mengetahui keadaan kemandirian belajar di SMP Negeri 1 Banyuasin III. Maka peneliti menyebarkan angket sebanyak 18 butir soal. Dari setiap alternatif jawaban diberi skor sesuai dengan kualitasnya masingmasing, untuk mempermudah menganalisis dalam penganalisisannya maka setip butir soal mempunyai empat alternatif jawaban dimana masing-masing diberi skor yaitu "sangat setuju" diberi skor nilai 4, "setuju" diberi skor nilai 3, "ragu-ragu" diberi skor nilai 2, dan "tidak setuju" diberi skor nilai 1. Maka diperoleh "skor mentah" angket di SMP Negeri 1 Banyuasin III.

\section{Tabel 4.21}

Daftar Skor Angket Kemandirian Belajar

SMP Negeri 1 Banyuasin III

\begin{tabular}{|c|l|c|c|}
\hline No & \multicolumn{1}{|c|}{ Nama } & ket. & skor \\
\hline 1 & Abdullah Pratama & L & 62 \\
\hline 2 & Ade Satria Silaban & L & 58 \\
\hline
\end{tabular}


Vol. 2, No. 1, (Januari 2020): 45-59

\begin{tabular}{|c|c|c|c|}
\hline 3 & Adellia Agustina & $\mathrm{P}$ & 57 \\
\hline 4 & Adinda Putri Amarsya & $\mathrm{P}$ & 57 \\
\hline 5 & Adinda Putri Andini & $\mathrm{P}$ & 60 \\
\hline 6 & Boy Sandy & $\mathrm{L}$ & 63 \\
\hline 7 & Dewi Lastri & $\mathrm{P}$ & 48 \\
\hline 8 & Dia Aprilia & $\mathrm{P}$ & 43 \\
\hline 9 & Erinda Adya Zahra & $\mathrm{P}$ & 63 \\
\hline 10 & Helyansa & $\mathrm{L}$ & 61 \\
\hline 11 & Irvandira Kristiya & $\mathrm{P}$ & 64 \\
\hline 12 & Jhun Heryandra Putra & $\mathrm{L}$ & 71 \\
\hline 13 & Luthfia Meyrlina & $\mathrm{P}$ & 70 \\
\hline 14 & M.Yusuf & $\mathrm{L}$ & 67 \\
\hline 15 & Meisya Risqitha Rosalia & $\mathrm{P}$ & 61 \\
\hline 16 & Miftahul Jannah & $\mathrm{P}$ & 56 \\
\hline 17 & $\begin{array}{l}\text { Muhammad Nawal } \\
\text { Pastiyah }\end{array}$ & $\mathrm{L}$ & 59 \\
\hline 18 & Murni & $\mathrm{P}$ & 61 \\
\hline 19 & Nira Septiani & $\mathrm{P}$ & 66 \\
\hline 20 & Nirina Aura A & $\mathrm{P}$ & 61 \\
\hline 21 & Rana & $\mathrm{P}$ & 59 \\
\hline 22 & Rani & $\mathrm{P}$ & 57 \\
\hline 23 & Rasti Meilanda & $\mathrm{P}$ & 62 \\
\hline 24 & Raufadul Jannah & $\mathrm{P}$ & 66 \\
\hline 25 & Sandi & $\mathrm{L}$ & 52 \\
\hline 26 & Sania Erianti & $\mathrm{P}$ & 54 \\
\hline 27 & Sari Lia Ulfa & $\mathrm{P}$ & 55 \\
\hline 28 & Tanzilal Azizir R & $\mathrm{L}$ & 62 \\
\hline 29 & Wahid Hadi K & $\mathrm{P}$ & 71 \\
\hline 30 & Zahra Amelia P & $\mathrm{P}$ & 62 \\
\hline
\end{tabular}


Berdasarkan tabel diatas, maka diperoleh "skor mentah"angket kemandirian belajar di SMP Negeri 1 Banyuasin III.

$\begin{array}{llllllllll}62 & 58 & 57 & 57 & 60 & 63 & 48 & 43 & 63 & 61 \\ 64 & 71 & 70 & 67 & 61 & 56 & 59 & 61 & 66 & 61 \\ 59 & 57 & 62 & 66 & 52 & 54 & 55 & 62 & 71 & 62\end{array}$

Dari data mentah hasil angket siswa diatas selanjutnya menentukan Range dan Interval yaitu dengan menggunakan rumus sebagai berikut :

a. Menetukan Range $=\mathrm{H}-\mathrm{L}$

Ket :

$$
\begin{aligned}
& \mathrm{R}=\text { Range } \\
& \mathrm{H}=\text { Nilai Tertinggi } \\
& \mathrm{L}=\text { Nilai Terendah }
\end{aligned}
$$

Jadi, $\mathrm{R}=\mathrm{H}-\mathrm{L}$

$$
\begin{aligned}
& =71-43 \\
& =28
\end{aligned}
$$

b. Menentukan $\mathrm{K}=1+3,33 \log \mathrm{N}$

$$
\begin{aligned}
=1+3,33 & \log 30 \\
& =1+3,33(1,48) \\
& =1+4,92 \\
& =5,92 \\
& =6
\end{aligned}
$$

c. Menentukan Interval dan Panjang Kelas $\mathrm{I}=\frac{R}{K}$ $\mathrm{I}=\frac{R}{K}=\frac{28}{6}=4,87$ dibulatkan menjadi 5

Setelah itu dari skor mentah angket kemandirian belajar di SMP Negeri 1 Banyuasin III di atas di distribusikan ke dalam tabel distribusi frekuensi untuk mempermudah pekerjaan dan mendapatkan nilai Mean pada Variabel X. Selanjutnya mencari nilai rata-rata (Mean) dengan menggunkan rumus sebagai berikut:

$\bar{X}=\frac{\sum f i x i}{\sum f i}$ 
Vol. 2, No. 1, (Januari 2020): 45-59

$$
\begin{aligned}
\bar{X} & =\frac{1,795}{30} \\
& =59,83 \text { dibulatkan menjadi } 60
\end{aligned}
$$

Setelah diketahui rata-rata (Mean) selanjutnya mencari Standar Deviasi dengan menggunakan rumus sebagai berikut :

$$
\begin{aligned}
\mathrm{SD}_{\mathrm{x}} & =\frac{\sqrt{\sum F i\left((\mathbf{X i}-\bar{X})^{2}\right.}}{\left(\sum \mathrm{Fi}-1\right)} \\
\mathrm{SD}_{\mathrm{x}} & =\frac{\sqrt{1.027,2}}{30-1} \\
& =\frac{\sqrt{1.027,2}}{29} \\
& =\sqrt{35,41} \\
& =5,95
\end{aligned}
$$

Setelah nilai rata-rata (Mean) dan Standar Deviasi (SD) diketahui, maka selanjutnya menentukan batasan untuk nilai tinggi, sedang dan rendah dengan menggunkan rumus TSR sebagai berikut :

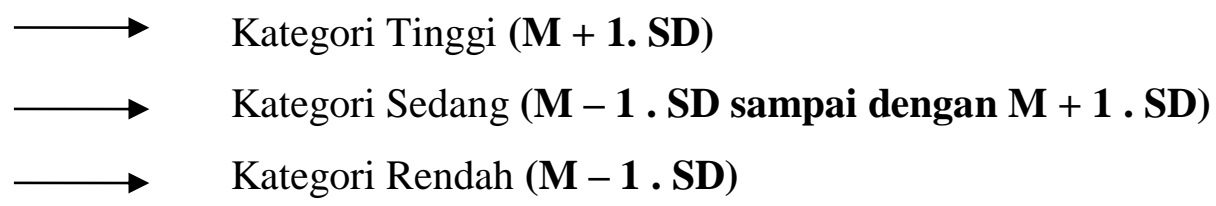

Setelah mengelompokkan skor kemandirian belajar dengan rumus TSR, maka langkah selanjutnya kemandirian belajar siswa yang tergolong tinggi sebanyak 3 orang atau (10\%), yang tergolong sedang sebanyak 23 orang atau $(76,66 \%)$, dan yang tergolong rendah sebanyak 4 orang atau $(13,33 \%)$. Dari hasil diatas menunjukkan bahwa kategori sedang yaitu 76,66\% menjadi jawaban dari rata-rata dari kemandirian belajar siswa di SMP Negeri 1 Banyuasin III.

\section{B. Hasil Belajar Siswa Kelas VII.A Pada Mata Pelajaran Pendidikan Agama Islam di SMP Negeri 1 Banyuasin III}

Untuk mengetahui hasil belajar siswa di SMP Negeri 1 Banyuasin III, peneliti mengambil hasil nilai MID semester tahun ajaran 2018-2019 pada mata pelajaran pendidikan Agama Islam. Untuk lebih jelasnya dapat dilihat pada tabel: 
Tabel 4. 24

Daftar Skor Hasil Belajar Siswa SMP Negeri 1 Banyuasin III

\begin{tabular}{|c|c|c|c|}
\hline No & Nama & ket. & skor \\
\hline 1 & Abdullah Pratama & $\mathrm{L}$ & 96 \\
\hline 2 & Ade Satria Silaban & $\mathrm{L}$ & 96 \\
\hline 3 & Adellia Agustina & $\mathrm{P}$ & 96 \\
\hline 4 & Adinda Putri Amarsya & $\mathrm{P}$ & 96 \\
\hline 5 & Adinda Putri Andini & $\mathrm{P}$ & 95 \\
\hline 6 & Boy Sandy & $\mathrm{L}$ & 95 \\
\hline 7 & Dewi Lastri & $\mathrm{P}$ & 95 \\
\hline 8 & Dia Aprilia & $\mathrm{P}$ & 95 \\
\hline 9 & Erinda Adya Zahra & $\mathrm{P}$ & 95 \\
\hline 10 & Helyansa & $\mathrm{L}$ & 95 \\
\hline 11 & Irvandira Kristiya & $\mathrm{P}$ & 95 \\
\hline 12 & Jhun Heryandra Putra & $\mathrm{L}$ & 95 \\
\hline 13 & Luthfia Meyrlina & $\mathrm{P}$ & 95 \\
\hline 14 & M.Yusuf & $\mathrm{L}$ & 94 \\
\hline 15 & Meisya Risqitha Rosalia & $\mathrm{P}$ & 94 \\
\hline 16 & Miftahul Jannah & $\mathrm{P}$ & 94 \\
\hline 17 & $\begin{array}{l}\text { Muhammad Nawal } \\
\text { Pastiyah }\end{array}$ & $\mathrm{L}$ & 89 \\
\hline 18 & Murni & $\mathrm{P}$ & 88 \\
\hline 19 & Nira Septiani & $\mathrm{P}$ & 88 \\
\hline 20 & Nirina Aura A & $\mathrm{P}$ & 88 \\
\hline 21 & Rana & $\mathrm{P}$ & 87 \\
\hline 22 & Rani & $\mathrm{P}$ & 85 \\
\hline 23 & Rasti Meilanda & $\mathrm{P}$ & 85 \\
\hline 24 & Raufadul Jannah & $\mathrm{P}$ & 85 \\
\hline 25 & Sandi & $\mathrm{L}$ & 85 \\
\hline 26 & Sania Erianti & $\mathrm{P}$ & 84 \\
\hline
\end{tabular}


Vol. 2, No. 1, (Januari 2020): 45-59

\begin{tabular}{|l|l|l|l|}
27 & Sari Lia Ulfa & $\mathrm{P}$ & 84 \\
\hline 28 & Tanzilal Azizir R & $\mathrm{L}$ & 80 \\
\hline 29 & Wahid Hadi K & $\mathrm{P}$ & 79 \\
\hline 30 & Zahra Amelia P & $\mathrm{P}$ & 78 \\
\hline
\end{tabular}

Berdasarkan tabel di atas, maka diperoleh data hasil belajar siswa SMP Negeri 1 Banyuasin III, sebagaimana disajikan dalam bentuk data mentah di bawah ini :

$\begin{array}{llllllllll}96 & 96 & 96 & 96 & 95 & 95 & 95 & 95 & 95 & 95 \\ 95 & 95 & 95 & 94 & 94 & 94 & 89 & 88 & 88 & 88 \\ 87 & 85 & 85 & 85 & 85 & 84 & 84 & 80 & 79 & 78\end{array}$

Dari data mentah diatas, selanjutnya menentukan Range dan Interval yaitu dengan menggunakan rumus sebagai berikut :

a. Menentukan Range $=\mathrm{H}-\mathrm{L}$

Ket $: \mathrm{R}=$ Range

$$
\begin{aligned}
& \mathrm{H}=\text { Nilai Tertinggi } \\
& \mathrm{L}=\text { Nilai Terendah }
\end{aligned}
$$

$$
\text { Jadi, } \begin{aligned}
\mathrm{R} & =\mathrm{H}-\mathrm{L} \\
& =96-78 \\
& =18
\end{aligned}
$$

b. Menentukan $\mathrm{K}=1+3,33 \log \mathrm{N}$

Jadi, $\mathrm{K}=1+3,33 \log \mathrm{N}$

$$
\begin{aligned}
& =1+3,33 \log 30 \\
& =1+3,33(1,48) \\
& =1+4,92 \\
& =5,92 \\
& =6
\end{aligned}
$$

c. Menentukan Interval dan Panjang Kelas $\mathrm{I}=\mathrm{I}=\frac{R}{K}$

$$
\mathrm{I}=\frac{R}{K}=\frac{18}{6}=3
$$


Setelah itu, mencari nilai rata-rata (Mean) dengan menggunkan rumus sebagai berikut:

$$
\begin{aligned}
& \bar{X}=\frac{\sum f i x i}{\sum f i} \\
& \bar{X}=\frac{2703}{30} \\
& =90,1
\end{aligned}
$$

Setelah diketahui rata-rata (Mean) selanjutnya mencari Standar Deviasi dengan menggunakan rumus sebagai berikut :

$$
\begin{aligned}
\mathrm{SD}_{\mathrm{y}} & =\frac{\sqrt{\sum F i\left((\mathbf{Y i}-\overline{\mathrm{Y}})^{2}\right.}}{\left(\sum \mathrm{Fi}-1\right)} \\
\mathrm{SD}_{\mathrm{y}} & =\frac{\sqrt{920,7}}{30-1} \\
& =\frac{\sqrt{920,7}}{29} \\
& =\sqrt{31,75} \\
& =5,63 \text { dibulatkan menjadi } 6
\end{aligned}
$$

Setelah nilai rata-rata (Mean) dan Standar Deviasi (SD) diketahui, maka selanjutnya menentukan batasan untuk nilai tinggi, sedang dan rendah dengan menggunkan rumus TSR sebagai berikut :

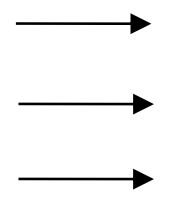

Kategori Tinggi $(\mathbf{M}+\mathbf{1}$. SD)

\section{Kategori Sedang (M - 1 . SD sampai dengan M + 1 . SD)}

Kategori Rendah (M - $\mathbf{1}$. SD)

Hasil belajar yang tergolong tinggi sebanyak 4 orang atau $(13,33 \%)$, yangtergolong sedang sebanyak 21 orang atau $(70 \%)$, dan yang tergolong rendah sebanyak 5 orang atau (16,66\%). Dari hasil diatas menunjukkan bahwa kategori sedang yaitu 70\% di SMP Negeri 1 Banyuasin III.

C. Analisis Hubungan Kemandirian Belajar Dengan Hasil Belajar Siswa Kelas VII.A Pada Mata Pelajaran Pendidikan Agama Islam di SMP Negeri 1 Banyuasin III

Pengujian hipotesis dalam penelitian ini menggunakan rumus korelasi Product Moment (Pearson) dengan menggunakan dua variabel bertujuan 
Vol. 2, No. 1, (Januari 2020): 45-59

untuk mencari hubungan antara dua variabel. Adapun hipotesis dalam penelitian ini sebagai berikut :

Ha : Ada hubungan antara kemandirian belajar dengan hasil belajar siswa pada mata pelajaran PAI di SMP Negeri 1 Banyuasin III.

Ho : Tidak ada hubungan antara kemandirian belajar dengan hasil belajar siswa pada mata pelajaran PAI di SMP Negeri 1 Banyuasin III.

Mencari Hasil Product Moment

$$
r_{\mathrm{xy}}=\frac{\mathrm{N}\left(\sum X Y\right)-\left(\sum X \cdot \sum Y\right)}{\sqrt{\left[\left(N \sum X_{n}^{2}-\left(\sum X\right) \frac{2}{n}\right)\right]\left[\left(N \sum Y_{n}^{2}-\left(\sum Y\right) \frac{2}{n}\right)\right]}}
$$

Setelah diketahui nilai $\mathrm{r}_{\mathrm{xy}}$ maka selanjutnya untuk memberikan interprestasi terhadap nilai di atas, maka dapat dilihat nilai "r" tabel (Product Moment) baik pada taraf signifikan $5 \%$ maupun pada taraf signifikan $1 \%$ dengan menghitung df-nya terlebih dahulu dengan rumus $\mathrm{df}=\mathrm{N}-2$ yaitu $30-2=28$ yang terdapat dalam tabel. Dengan $\mathrm{df}=28$ diperoleh pada taraf signifikan $5 \%$ sebesar 0,374 dan taraf signifikan $1 \%$ sebesar 0,478. Dari hasil tersebut terlihat bahwa nilai $r_{x y}(0,552)$ lebih besar dari taraf signifikan $5 \%$ maupun taraf signifikan $1 \%$ dengan perbandingan $(0,374<0,552>0,478)$ Dengan demikian maka hipotesis alternatif $H_{a}$ diterima dan $H_{o}$ ditolak yang berarti ada Hubungan positif yang signifikan antara variabel X (Kemandirian Belajar) dengan variabel Y (Hasil Belajar).

\section{KESIMPULAN}

Berdasarkan analisis yang telah dilakukan maka penelitian ini disimpulkan sebagai berikut :

1. Berdasarkan hasil analisis variabel kemandirian belajar siswa kelas VII.A di SMP Negeri 1 Banyuasin III, dihasilkan nilai berikut: untuk kategori tinggi dengan persentase sebesar $10 \%$ sebanyak 3 responden, pada kategori sedang dengan persentase sebesar 76,66\% sebanyak 23 responden dan pada kategori rendah dengan persentase sebesat 13,33\% sebanyak 4 responden. Jadi dapat disimpulkan, kecenderuangan kemandirian belajar siswa kelas VII.A di SMP 
Negeri 1 Banyuasin III berada pada kategori sedang sebesar 76,66\% sebanyak 23 responden.

2. Berdasarkan hasil analisis variabel hasil belajar siswa kelas VII.A di SMP Negeri 1 Banyuasin III, dihasilkan nilai berikut: untuk kategori tinggi dengan persentase sebesar 13,33\% sebanyak 4 responden, pada kategori sedang dengan persentase sebesar $70 \%$ sebanyak 21 responden dan pada kategori rendah dengan persentase sebesar 16,66\% sebanyak 5 responden. Jadi dapat disimpulkan, kecenderuangan hasil belajar siswa kelas VII.A di SMP Negeri 1 Banyuasin III berada pada kategori sedang sebesar $70 \%$ sebanyak 21 responden.

3. Ada hubungan yang signifikan antara kemandirian belajar dengan hasil belajar siswa kelas VII.A pada mata pelajaran Pendidikan Agama Islam di SMP Negeri 1 Banyuasin III. Berdasarkan perhitungan uji hipotesis diperoleh $\mathrm{t}_{\text {hitung }}=0,552$ dan $\mathrm{t}_{\text {tabel }}=0,374$ dengan taraf signifikan $5 \%$ dan kriteria pengujian $\mathrm{H}_{0}$ di tolak dan $\mathrm{H}_{\mathrm{a}}$ diterima jika $t_{\text {hitung }}>\mathrm{t}_{\text {tabel }}$. Pada penelitian ini diperoleh $\mathrm{t}_{\text {hitung }}=0,552>\mathrm{t}_{\text {tabel }}=0,374$ maka $\mathrm{H}_{\mathrm{a}}$ diterima yaitu ada hubungan yang signifikan antara kemandirian belajar dengan hasil belajar siswa kelas VII.A pada mata pelajaran Pendidikan Agama Islam di SMP Negeri 1 Banyuasin III . 


\section{DAFTAR PUSTAKA}

Ali, M., dan Anshori. Psikologi Pendidikan. Jakarta: Rineka Cipta, 2010.

Arikunto, Suharsimi. Prosedur Penelitian Suatu Pendekatan Praktek. Jakarta: Rineka Cipta, 2013.

Hasil Observasi Lapangan di SMPN 1 Banyuasin III pada tanggal 23 Januari 2019

Karliana, K. "Pengaruh penerapan investigasi kelompok dibantu dengan multimediainteraktif terhadap peningkatan hasil belajar siswa pada mata pelajaran PAI di SMA Yanitas Palembang." Tadrib: Jurnal Pendidikan Agama Islam 2, no. 1 (2017): 1-26.

Nurastanti, Fajri Ismail, dan Sukirman. "Pengaruh lingkungan belajar di sekolah terhadap hasil belajar siswa pada mata pelajaran fiqih kelas XI Madrasah Aliyah Negeri 1 Banyuasin.” Jurnal PAI Raden Fatah 1, no. 1 (2017): 41-46.

Ratnaningsih. "Pengaruh Pembelajaran Kontekstual terhadap Kemampuan Berpikir Kritis dan Kreatif Matematik serta Belajar mandiri Siswa Sekolah Menengah Atas.” Disertasi UPI Bandung, 2007.

Sudijono, Anas. Pengantar Evaluasi Pendidikan. Jakarta: Grafindo Prasada, 2015.

Syah, Muhibbin. Psikologi Belajar. Depok: Rajawali Pers, 2017. 